\title{
The diagnosis of Hodgkin's disease in surgically excised spleens
}

\author{
GEOFFREY FARRER-BROWN, M. H. BENNETT, C. V. HARRISON, \\ YVONNE MILLETT, AND A. M. JELLIFFE
}

From the Bland-Sutton Institute of Pathology and the Radiotherapy Department, Middlesex Hospital, London, and the Pathology Departments of the Mount Vernon Hospital, Northwood, Middlesex, and the Royal Postgraduate Medical School, London

SYNOPSIS A series of 44 spleens removed from patients with Hodgkin's disease before treatment has been reviewed. The difficulties encountered in detecting foci of Hodgkin's tissue and the histological features and characteristics of early invasion are described.

In a proportion of cases of Hodgkin's disease failure of treatment is due to the presence of undetected foci of disease outside the treated area, and in particular foci in the spleen. To overcome this difficulty Glatstein, Guernsey, Rosenberg, and Kaplan (1969), Glatstein, Trueblood, Enright, Rosenberg, and Kaplan (1970), and Jelliffe, Millett, Marston, Bennett, Farrer-Brown, Kendall, and Keeling (1970) have recommended laparotomy with splenectomy before the start of therapy. This permits accurate assessment of the extent of the disease and consequently proper therapeutic management and it also removes a focus of disease in an organ that is difficult to treat. There is reason to believe that splenectomy in appropriate cases improves the chances of long-term survival and consequently it is likely to be undertaken more often, with the result that pathologists will be asked to study spleens early in the course of the disease. It is the purpose of this communication to draw attention to the difficulties in diagnosis that we have encountered in a series of 44 spleens, ${ }^{1}$ removed as a diagnostic procedure from patients with Hodgkin's disease at the Middlesex and Harefield Hospitals and the Royal Postgraduate Medical School between April 1970 and May 1971. The histological appearances in early splenic involvement are varied but this study has revealed certain characteristic patterns.

\section{Method}

All spleens were weighed, measured, and cut into

${ }^{1}$ This series of spleens forms part of the material submitted to the National Lymphoma Investigation (Clinical Cancertherapy Cooperative Group) which commenced in February 1970.

Received for publication 21 October 1971. two or more slices, depending on size, to obtain good fixation. When fixed they were examined grossly and if no obvious deposits were seen the spleens were sliced as thinly as possible $(2-3 \mathrm{~mm})$ in order to detect single minute foci. If no abnormality was apparent the general size of the Malpighian bodies was assessed and blocks taken that included the largest Malpighian bodies as these were the most likely sites of early involvement. Sections were stained by routine histological methods.

\section{Results}

Details of the patients, with involved and uninvolved spleens plus the splenic weight and the histological type of Hodgkins's disease (Rye Classification, Lukes, Craven, Hall, Rappaport, and Ruben, 1966) of the original lymph node, are shown in Tables $I$ and II.

The age range of the 32 male and 12 female 옥 patients was 11-77 years with a median of 30 years. $\frac{D}{2}$ Twenty-two uninvolved spleens weighed between 100 and $690 \mathrm{~g}$ while the weights of the 22 spleens $N$ containing Hodgkin's tissue ranged from 77 to $870 \mathrm{~g}$ (Fig. 1). The median weight of involved spleens $O$ $(304 \mathrm{~g})$ was $112 \mathrm{~g}$ heavier than those that were un- $\omega$ involved (192 $\mathrm{g})$. A normal weight did not exclude involvement and an abnormally heavy spleen was $\varrho$ often uninvolved by malignant lymphoma.

In 14 of the 22 involved spleens abnormal nodules $\stackrel{\oplus}{+}$ were easily detectable on macroscopic examination 70 but in two spleens only single nodules $3 \mathrm{~mm}$ and $2 \mathrm{~mm}$ respectively were present (Fig. 2). A further $\stackrel{\mathbb{D}}{\overparen{D}}$ three spleens contained only two to five small foci $\stackrel{\mathbb{Q}}{\varrho}$ up to $7 \mathrm{~mm}$ diameter. Three specimens with only slight prominence of the Malpighian bodies (Fig. 3) 


\begin{tabular}{|c|c|c|c|c|c|c|}
\hline \multirow{2}{*}{$\begin{array}{l}\text { Rye Classification of } \\
\text { Original Lymph Node }\end{array}$} & \multirow[t]{2}{*}{ Case No. } & \multicolumn{3}{|l|}{ Patient } & \multirow[t]{2}{*}{ Hospital } & \multirow{2}{*}{$\begin{array}{l}\text { Spleen } \\
\text { Weight } \\
(g)\end{array}$} \\
\hline & & Initials & Sex & Age & & \\
\hline Lymphocytic predominant & $\begin{array}{l}4 \\
25 \\
28 \\
36 \\
37 \\
39\end{array}$ & $\begin{array}{l}\text { WW } \\
\text { AL } \\
\text { MH } \\
\text { RM } \\
\text { AS } \\
\text { SB }\end{array}$ & $\begin{array}{l}\mathbf{M} \\
\mathbf{M} \\
\mathbf{F} \\
\mathbf{M} \\
\mathbf{M} \\
\mathbf{F}\end{array}$ & $\begin{array}{l}55 \\
56 \\
37 \\
52 \\
75 \\
45\end{array}$ & $\begin{array}{l}\text { Middlesex } \\
\text { Royal Postgraduate Medical School } \\
\text { Middlesex } \\
\text { Harefield } \\
\text { Harefield } \\
\text { Middlesex }\end{array}$ & $\begin{array}{l}550 \\
660 \\
280 \\
- \\
-\end{array}$ \\
\hline Nodular sclerotic & $\begin{array}{l}1 \\
8 \\
11 \\
12 \\
13 \\
14 \\
24 \\
26 \\
38 \\
43 \\
44\end{array}$ & $\begin{array}{l}\text { MP } \\
\text { KE } \\
\text { CB } \\
\text { GC } \\
\text { PJ } \\
\text { CM } \\
\text { RB } \\
\text { DC } \\
\text { CC } \\
\text { DE } \\
\text { HC }\end{array}$ & $\begin{array}{l}\mathbf{M} \\
\mathbf{M} \\
\mathbf{M} \\
\mathbf{M} \\
\mathbf{F} \\
\mathbf{M} \\
\mathbf{M} \\
\mathbf{M} \\
\mathbf{F} \\
\mathbf{M} \\
\mathbf{M}\end{array}$ & $\begin{array}{l}16 \\
15 \\
59 \\
23 \\
38 \\
28 \\
31 \\
35 \\
24 \\
47 \\
46\end{array}$ & $\begin{array}{l}\text { Middlesex } \\
\text { Middlesex } \\
\text { Middlesex } \\
\text { Middlesex } \\
\text { Middlesex } \\
\text { Middlesex } \\
\text { Middlesex } \\
\text { Middlesex } \\
\text { Middlesex } \\
\text { Royal Postgraduate Medical School } \\
\text { Middlesex }\end{array}$ & $\begin{array}{l}385 \\
254 \\
175 \\
870 \\
149 \\
213 \\
480 \\
206 \\
394 \\
313 \\
495\end{array}$ \\
\hline Mixed cellularity & $\begin{array}{r}7 \\
15 \\
29 \\
35 \\
41\end{array}$ & $\begin{array}{l}\text { TMG } \\
\text { JB } \\
\text { RR } \\
\text { EM } \\
\text { FC }\end{array}$ & $\begin{array}{l}\mathbf{M} \\
\mathbf{M} \\
\mathbf{M} \\
\mathbf{M} \\
\mathbf{M}\end{array}$ & $\begin{array}{l}25 \\
40 \\
22 \\
58 \\
77\end{array}$ & $\begin{array}{l}\text { Middlesex } \\
\text { Middlesex } \\
\text { Middlesex } \\
\text { Middlesex } \\
\text { Royal Postgraduate Medical School }\end{array}$ & $\begin{array}{r}77 \\
370 \\
250 \\
505 \\
295\end{array}$ \\
\hline
\end{tabular}

Table I Details of patients with involved spleens

\begin{tabular}{|c|c|c|c|c|c|c|}
\hline \multirow{2}{*}{$\begin{array}{l}\text { Rye Classification of } \\
\text { Original Lymph Node }\end{array}$} & \multirow[t]{2}{*}{ Case No. } & \multicolumn{3}{|l|}{ Patient } & \multirow[t]{2}{*}{ Hospital } & \multirow{2}{*}{$\begin{array}{l}\text { Spleen } \\
\text { Weight } \\
(\mathrm{g})\end{array}$} \\
\hline & & Initials & Sex & Age & & \\
\hline Lymphocyte predominant & 33 & $\mathbf{A M}$ & $\mathbf{M}$ & 21 & Middlesex & 195 \\
\hline Nodular sclerotic & $\begin{array}{r}2 \\
3 \\
9 \\
10 \\
16 \\
17 \\
18 \\
19 \\
20 \\
22 \\
31 \\
42\end{array}$ & $\begin{array}{l}\text { EB } \\
\text { CF } \\
\text { SL } \\
\text { MW } \\
\text { SM } \\
\text { EM } \\
\text { RP } \\
\text { EG } \\
\text { AR } \\
\text { AP } \\
\text { SZ } \\
\text { WW }\end{array}$ & $\begin{array}{l}\mathbf{M} \\
\mathbf{F} \\
\mathbf{F} \\
\mathbf{F} \\
\mathbf{F} \\
\mathbf{F} \\
\mathbf{M} \\
\mathbf{F} \\
\mathbf{M} \\
\mathbf{F} \\
\mathbf{M} \\
\mathbf{F}\end{array}$ & $\begin{array}{l}22 \\
36 \\
22 \\
11 \\
24 \\
20 \\
19 \\
19 \\
30 \\
29 \\
26 \\
60\end{array}$ & $\begin{array}{l}\text { Middlesex } \\
\text { Middlesex } \\
\text { Middlesex } \\
\text { Middlesex } \\
\text { Middlesex } \\
\text { Middlesex } \\
\text { Middlesex } \\
\text { Middlesex } \\
\text { Middlesex } \\
\text { Middlesex } \\
\text { Middlesex } \\
\text { Middlesex }\end{array}$ & $\begin{array}{l}155 \\
255 \\
140 \\
100 \\
255 \\
205 \\
321 \\
204 \\
160 \\
105 \\
163 \\
165\end{array}$ \\
\hline Mixed cellularity & $\begin{array}{r}5 \\
6 \\
21 \\
23 \\
27 \\
30 \\
32 \\
34 \\
40\end{array}$ & $\begin{array}{l}\text { DB } \\
\text { MS } \\
\text { FK } \\
\text { BS } \\
\text { JM } \\
\text { JC } \\
\text { KB } \\
\text { AS } \\
\text { JO }\end{array}$ & $\begin{array}{l}\mathbf{M} \\
\mathbf{M} \\
\mathbf{M} \\
\mathbf{M} \\
\mathbf{M} \\
\mathbf{M} \\
\mathbf{M} \\
\mathbf{M} \\
\mathbf{M}\end{array}$ & $\begin{array}{l}24 \\
34 \\
33 \\
15 \\
28 \\
37 \\
35 \\
30 \\
57\end{array}$ & $\begin{array}{l}\text { Middlesex } \\
\text { Middlesex } \\
\text { Middlesex } \\
\text { Middlesex } \\
\text { Royal Postgraduate Medical School } \\
\text { Middlesex } \\
\text { Middlesex } \\
\text { Middlesex } \\
\text { Middlesex }\end{array}$ & $\begin{array}{l}360 \\
399 \\
690 \\
420 \\
180 \\
153 \\
164 \\
340 \\
125\end{array}$ \\
\hline
\end{tabular}

Table II Details of patients with uninvolved spleens

and no macroscopic discrete foci proved to be positive on histological examination.

The original lymph node biopsy from each patient had been classified histologically by three of the authors (M.H.B., G.F.-B., and C.V.H.) independently according to the Rye modification (Lukes et al, 1966) of the Lukes and Butler classification 


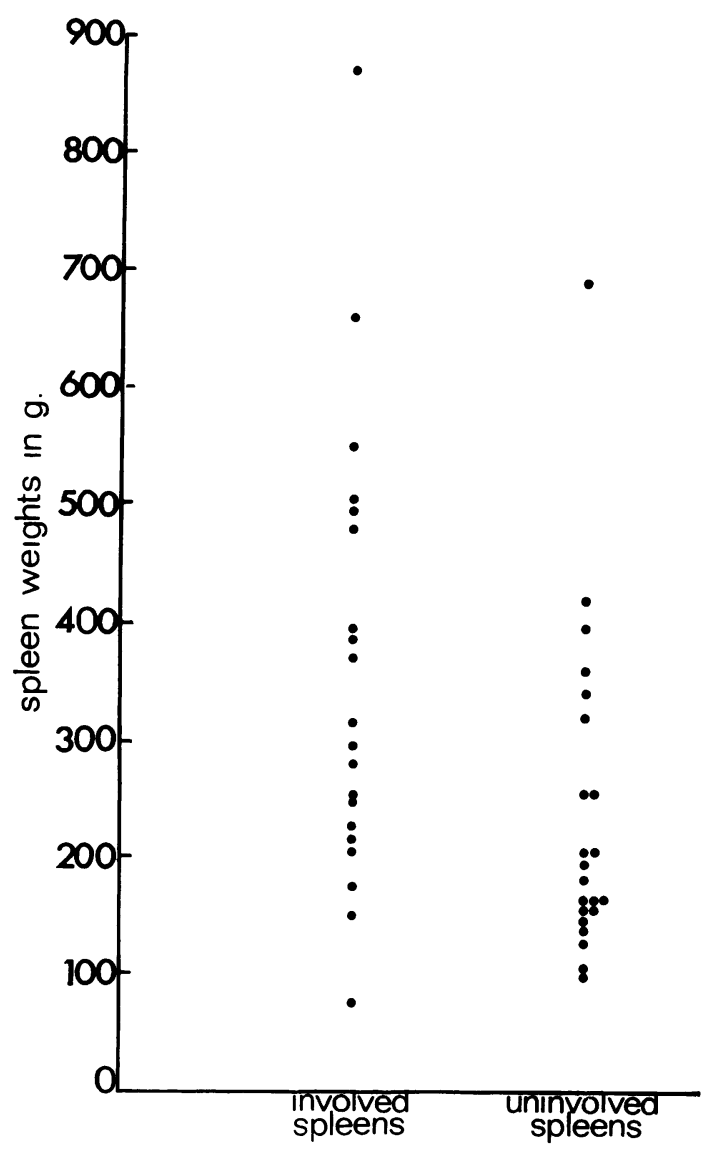

Fig. 2 The microscopical appearance of a single focus of Hodgkin's tissue in a $213 \mathrm{~g}$ spleen. Compare with the uninvolved Malpighian bodies. $H$ and $E \times 15$.

Fig. 1 The weights of uninvolved spleens and those involved by Hodgkin's tissue.

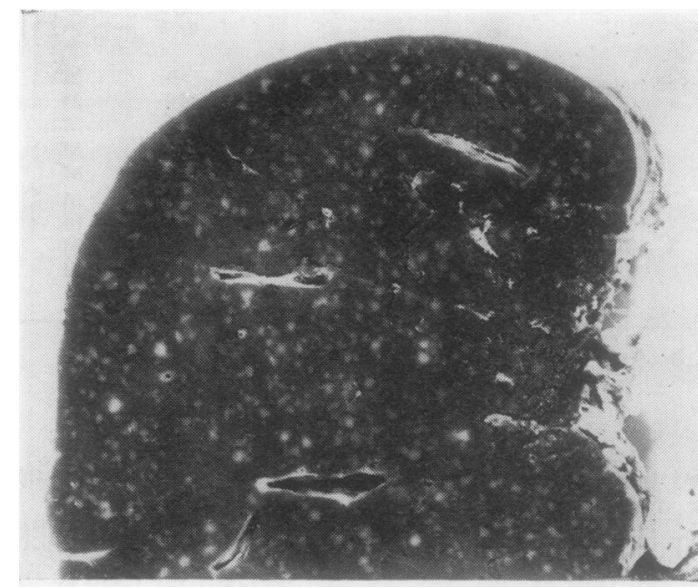

Fig. 3 A spleen, after fixation, with prominent Malpighian bodies all of which proved to be positive on histological examination. $\times 1.5$. 


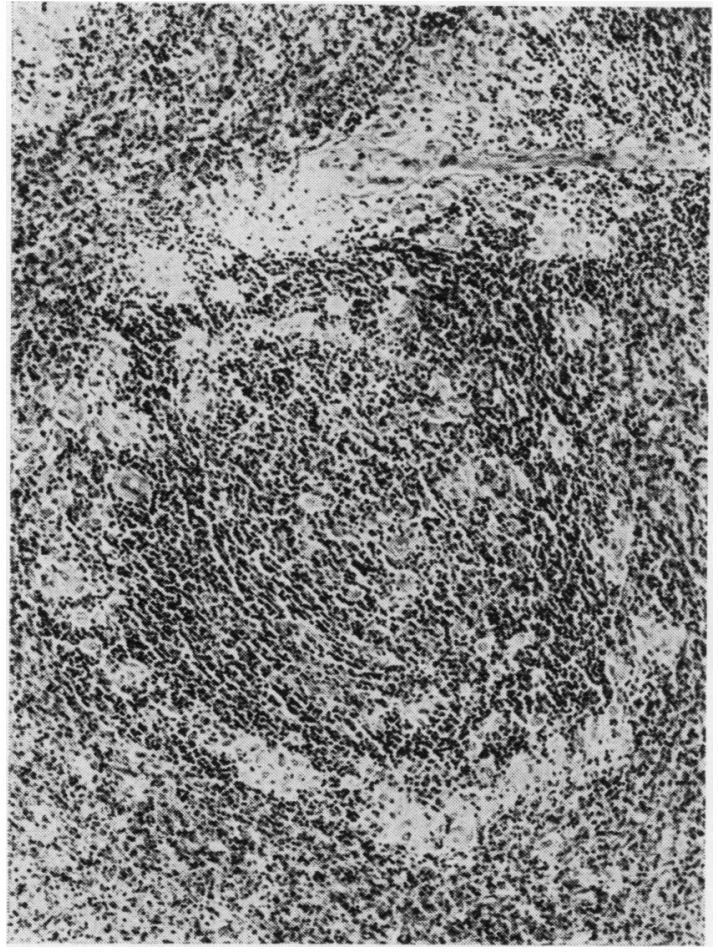

Fig. 4 Abnormal histiocytic cells present in the periarteriolar area at the top of the figure and at the periphery of the adjacent Malpighian body. $H$ and $E$ $\times 96$.

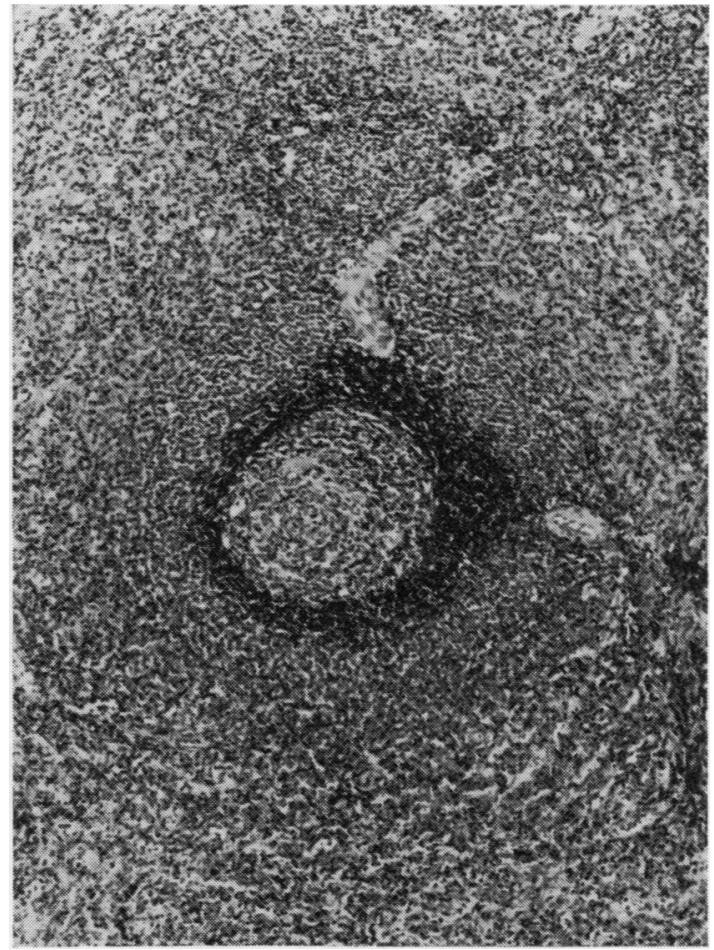

Fig. 5 A normal reversed follicle containing a reactive centre. The immature cells are peripheral to the dark staining mature cells surrounding the reactive centre. $H$ and $E \times 60$.

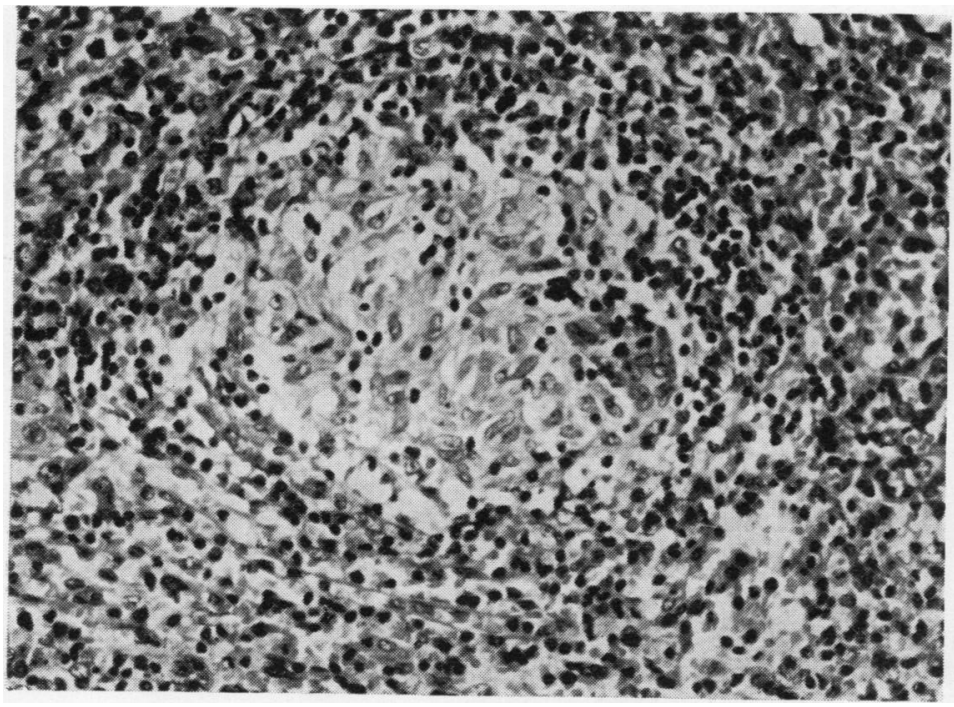

Fig. 6 Cluster of epithelioid histiocytic cells seen in a spleen involved by Hodgkin's disease. $H$ and $E \times 186$. 


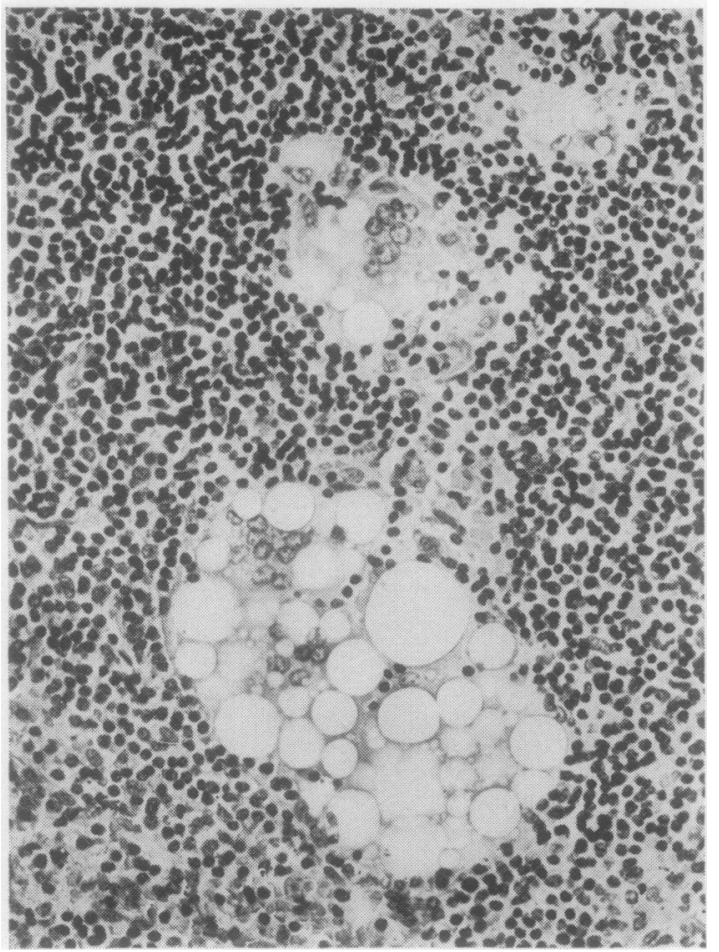

Fig. 7 'Lipophage' granulomata in a Malpighian body in an uninvolved spleen. $H$ and $E \times 168$.

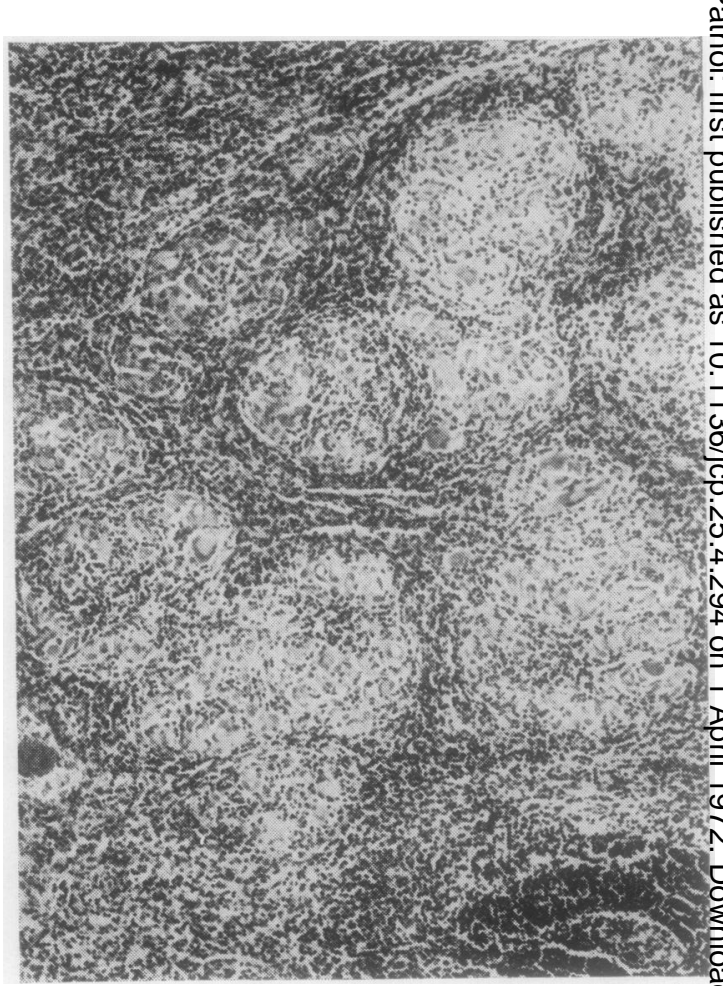

Fig. 8 'Sarcoid-like' granulomata seen in an uninvolved $\stackrel{\stackrel{2}{\perp}}{\rightarrow}$ spleen. $H$ and $E \times 66$.

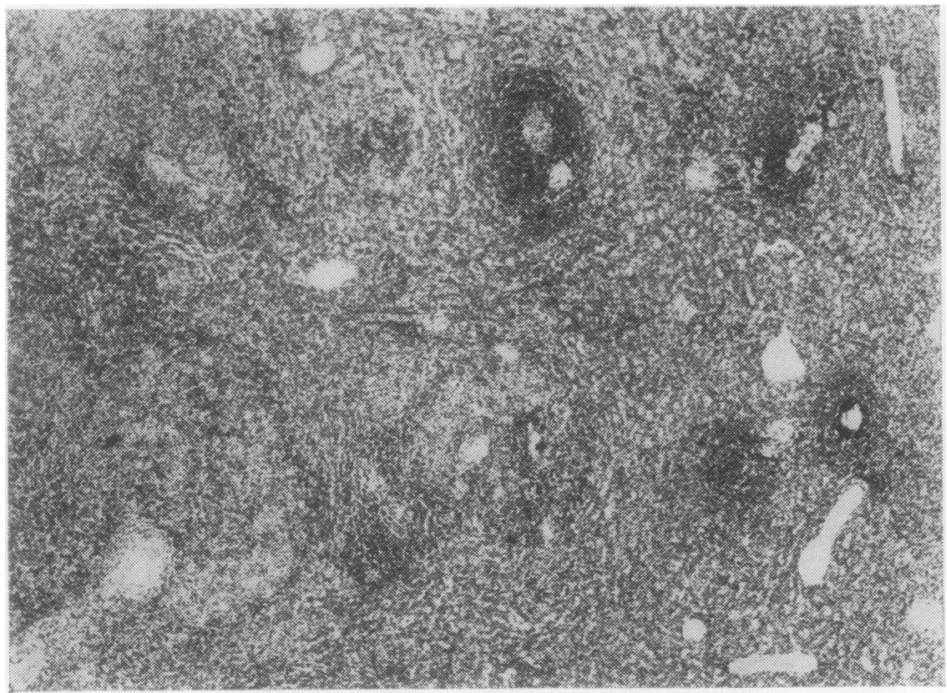

Fig. 9 Enlarged and ill defined Malpighian bodies involved by Hodgkin's disease adjacent to normal Malpighian bodies at the right of the 음. figure. $H$ and $E \times 24$. 


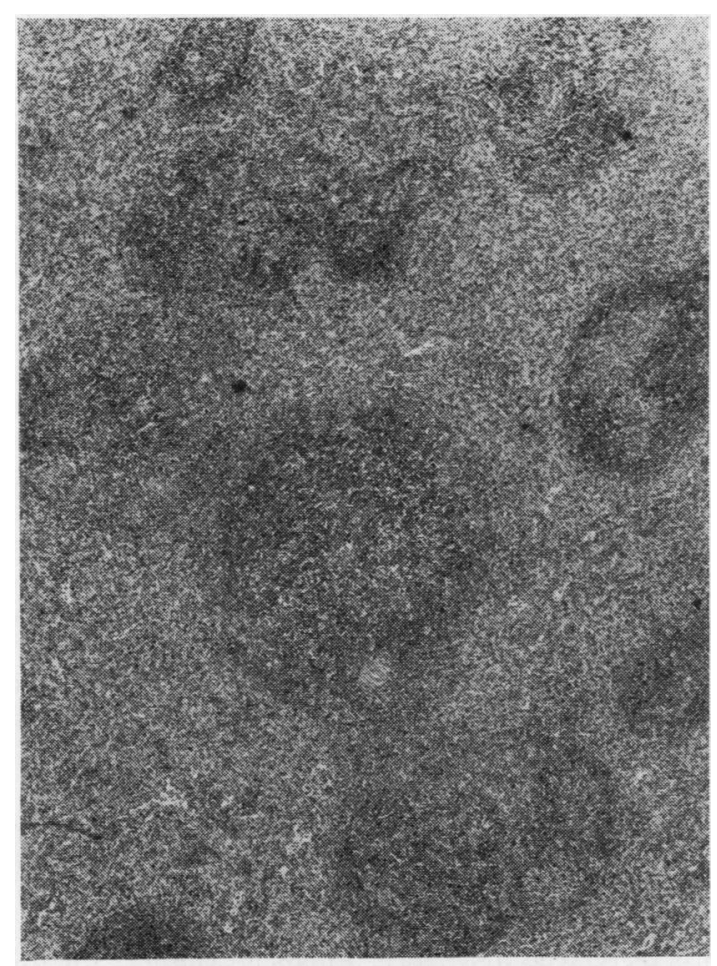

Fig. 10 Generalized enlargement of Malpighian bodies due to diffuse infiltration by Hodgkin's tissue. The magnification is similar to Figure 9. $H$ and $E \times 24$.

and five of 14 with mixed type disease had involved spleens. There were no patients with lymphocyticdepleted Hodgkin's disease in the original lymph node in this series of splenectomies.

An attempt has been made to apply the Rye histological classification to the appearances of Hodgkin's tissue in the spleen because early in this study it became apparent that the characteristic features of lymphocytic predominance or depletion, mixed cellularity type, and even nodular sclerosis may be present. In this series just over $45 \%$ of cases with involved spleens had the same histological type of Hodgkin's disease in the spleen as in the original lymph node. In $27 \%$ a lymphocytic-depleted appearance with diffuse fibrosis was present in the spleen although the lymph node histology was lymphocytic predominant, nodular sclerotic, or mixed in type. In contrast five of the 16 patients with nodular sclerotic or mixed cellularity lymph node histology showed a lymphocytic-predominant picture in the spleen.

Microscopical examination of the three spleens with no detectable gross abnormality except slightly prominent Malpighian bodies showed involvement of these lymphoid foci by Hodgkin's disease of the lymphocytic predominant type. In one specimen abnormal cells were present throughout the white pulp but in other instances they were confined to the periarteriolar areas and to the periphery of the lymphoid follicles (Fig. 4). When involvement was confined to these areas diagnostic Reed-Sternberg cells were relatively easy to detect in the mixed cellularity type of disease, but in the lymphocyticpredominant type of disease the only abnormality was often merely a rim of histiocytes and careful search was needed to detect Reed-Sternberg cells. These appearances must be distinguished from the reversed follicle often seen in normal spleens (Fig. 5). In three of the eight spleens with involvement by lymphocytic-predominant disease clusters of epithelioid histiocytes (Fig. 6), occasionally with giant cells, were present within both the red and white pulp. These histiocytic clusters contrasted with lipophage (Fig. 7) or sarcoid-like granulomata (Fig. 8) seen in other involved and uninvolved spleens.

Involved Malpighian bodies were nearly always enlarged compared with normal and were fairly easily detectable when adjacent to normal Malpighian bodies (Fig. 9), but it was less obvious when all lymphoid follicles showed uniform early involvement by Hodgkin's tissue (Fig. 10). A number of spleens showed that large foci of Hodgkin's tissue formed as a result of coalescence of the invaded Malpighian bodies.

\section{Discussion}

Careful gross examination of all spleens is essential to detect the presence of Hodgkin's disease. Initial slicing of the spleen is necessary to ensure adequate fixation. There is no absolute correlation between spleen weight and involvement of the organ. This is in agreement with the findings of Kadin, Glatstein, and Dorfman (1971) who, in their clinicopathological study of 117 untreated patients subjected to laparotomy, reported on the frequency of Hodgkin's disease in spleens of normal weight and size. Large spleens may not be involved while small spleens may contain foci of lymphoma. In general the larger the spleen the more obvious are the nodules of Hodgkin's tissue but all spleens which are not obviously involved must be sliced as thinly as possible to detect minute foci. On occasion the only suspicious macroscopic finding will be slightly prominent Malpighian bodies which may appear slightly whiter than normal. If no gross abnormality is detectable the blocks taken should contain the largest Malpighian bodies visible in order to exclude early microscopic invasion. 
This study has shown the variation in histological appearances that may be present in early involvement of the spleen by Hodgkin's disease. Involvement appears to begin in the periarteriolar area and periphery of the Malpighian bodies after which this lymphoid tissue becomes diffusely infiltrated. At this early stage detection of the lymphocytic and histiocytic type of disease may be difficult, particularly if abnormal cells are confined to the periphery of the Malpighian bodies rather than involving them diffusely. The above features should not be confused with two benign appearances of the lymphoid tissue of the spleen, neither of which show any correlation with the likelihood of involvement of the organ by Hodgkin's disease. The first is the 'reversed follicle', often seen in normal spleens, when the Malpighian bodies contain central, mature lymphocytes surrounded by less mature cells (Klemperer, 1938), and secondly there is the presence of definite reactive centres in the Malpighian bodies.

Another diagnostic problem is the distinction between various types of granulomata seen in the spleen. It is well known that in lymph nodes with the lymphocytic-predominant type of Hodgkin's disease clusters of epithelioid histiocytes may give an impression of 'sarcoid-like' granulomata. This type of Hodgkin's granuloma was seen in the spleens in this study involved by either the lymphocytic-predominant or nodular-sclerotic types of disease. These clusters may be present within both the white and red pulp and, as diagnostic cells are usually very scanty, differentiation from classical sarcoid-like granulomata or lipophages may prove difficult. In the latter the presence of fat globules usually makes the diagnosis simple but occasionally globules are minimal and the foci of lipophages resemble 'epithelioid' granulomata with foreign body type giant cells. The cause of the lipophages is unknown. The significance of classical 'sarcoid-like' granulomata is more difficult to assess and in two uninvolved spleens in this series their significance remains obscure, but in agreement with Kadin et al (1971) we do not consider that they represent Hodgkin's disease, although possibly they may be a reaction to the condition. One was a $660-\mathrm{g}$ spleen from an Egyptian boy who had a mixed cellularity type of Hodgkin's disease in the right epitrochlear lymph nodes and had lived all his life in Egypt. The other was a 225-g spleen from an English girl with nodular sclerotic Hodgkin's disease in a right cervical lymph node. In neither of these cases could definite Hodgkin's tissue be found in the spleens.

No correlation was found between the histological type of Hodgkin's disease in the original lymph node and the likelihood of involvement of the spleen. Histological classification of the type of Hodgkin's disease in the spleen proved relatively easy, and it is interesting that in nearly half of cases with involved spleens the same histological type was present in the spleen as in the lymph node. A more lymphocytic predominant type of histology in the spleen compared with the lymph node was found only when involvement of the spleen was early. It is possible, however, that in some of these cases nodular sclerosis in the spleen had not yet become apparent as fibrous bands were not seen in early involvement of this organ. At this stage of involvement the diagnosis of nodular sclerosis may have to be made solely on the cellular component and the presence of lacunar cells. In just over a quarter of the spleens the histological type was worse in the spleen with features of lympho- i cytic depletion and yet in all cases laparotomy was performed as a diagnostic procedure within a few months of the initial diagnostic lymph node biopsy. Follow up of these patients will be particularly 음 interesting as at the present time the prognostic significance of histological progression of the disease is unknown.

The authors wish to thank the many clinicians and surgeons who referred patients for investigation and treatment. We are very grateful to Miss Jenny Abrahams, Miss Eileen Green, and Miss Linda Dean for secretarial assistance. Financial support for this work and for the Clinical Cancertherapy Cooperative Group has been generously provided by Eli Lilly \& Co, Roche Products Ltd, the J. S. Frazer Trust Fund, the Peggy Russell Memorial Fund, the New Court Charitable Trust, the Aitchison Charitable Trust, the Cancer Research Campaign, and many individuals who have a personal interest in this research programme.

\section{References}

Glatstein, E., Guernsey, J. M., Rosenberg, S. A., and Kaplan, H. S. (1969), The value of laparotomy and splenectomy in the staging of Hodgkin's disease. Cancer (Philad.), 24, 709-718.

Glatstein, E., Trueblood, H. W., Enright, L. P., Rosenberg, S. A., $>$ and Kaplan, H. S. (1970). Surgical staging of abdominal $\frac{}{O}$ involvement in unselected patients with Hodgkin's disease. 三. Radiology, 97, 425-432.

Jelliffe, A. M., Millett, Y. L., Marston, J. A. P., Bennett, M. H., Љ Farrer-Brown, G., Kendall, B., and Keeling, D. H. (1970). Laparotomy and splenectomy as routine investigations in the staging of Hodgkin's disease before treatment. Clin. Radiol., $\mathrm{N}$
$21,439-445$.

Kadin, M. E., Glatstein, E., and Dorfman, R. F. (1971). Clinicopathologic studies of 117 untreated patients subjected to laparotomy for the staging of Hodgkin's disease. Cancer (Philad.), 27, 1277-1294.

Klemperer, P. (1938). The spleen. Section XXI. In Handbook of Haematology, Vol. III, Sect. XXI, edited by H. Downey, p. 1661. Hoeber, New York.

Lukes, R. J., and Butler, J. J. (1966). The pathology and nomenclature of Hodgkin's disease. Cancer Res., 26, 1063-1081. (Discussion $\mathbb{D}$ by $H$. Rappaport, 1082-1083.)

Lukes, R. F., Craven, L. F., Hall, T. C., Rappaport, H., and Ruben, P. $\mathbb{D}$ (1966). Report of the Nomenclature Committee. Cancer Res., $\underset{\sigma}{\sigma}$
26, 1311. 